\title{
$J(\Theta)$
}

Received: 20.02 .2020

\section{Firdevsî̀nin Hayât u Memât Adlı Eseri ve İmlâ Özellikleri}

\section{Firdävsîs Work named Hayât u Mamât and its Orthographic Features}

\author{
Ayşe AYDin \& Ahmet ÇETİNKAyA \\ Sakarya University (Sakarya/Turkey) \\ E-mails: ayse@sakarya.edu.tr\&ahmet.cetinkaya3@ogr.sakarya.edu.tr
}

Hayât u Memât (1508), written by Firdevsî during this period spanning XIII.XVIth centuries, is one of these works. The work has an important place in terms of reflecting the language and spelling features of old Anatolian Turkish, containing the features of the translated works, and providing information about religious, mystical and moral issues. In our study, firstly, information was given about the Old Anatolian Turkish period and the religious, mystical and moral works written in this period, then the life, literary personality and works of Firdevsî, who was the author of the work, were mentioned, and then the presentation of Hayât $u$ Memât was introduced. The introduction section consists of examples of the external features, content and spelling features of the work.

Key Words: Old Anatolian Turkish, Firdevsî, Hayât u Memât, Religion, Sufism, Manuscripts. 


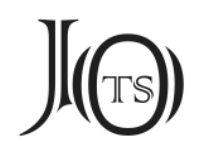

\section{Giriş}

Eski Anadolu Türkçesi, XIII. yüzyılda başlayarak XVI. yüzyıl başlarına kadar devam eden Batı Türkçesinin ilk döneminin adıdır. XVI. yüzyılda yerini Osmanlı Türkçesine bırakır (Ercilasun 2014: 438). Oğuz Türkçesi ilk olarak bu dönemde yazıya geçirildiği için Eski Anadolu Türkçesinin Türk Dili tarihi içerisindeki önemi büyüktür (Şahin 2003: 13).

TimuRTAş bu dönemi: "Eski Anadolu Türkçesi devresi, Selçuklular devri ile İstanbul'un fethi arasindaki zamanin (XII-XV.yüzyıllar) edebi dilidir. XV. yüzyılın ikinci yarısı hatta XVI. yüzyılın ilk çeyrek kısmı Klasik Osmanlıcaya geçiş devresini teşkil eder. Bu intikal devresinde de Eski Anadolu Türkçesi özellikleri hâkim durumdadır." (2011: 319) şeklinde tarif etmiştir.

KORKMAZ da Eski Anadolu Türkçesinin dönemlerini; Oğuzcanın Eski Anadolu Türkçesinden önceki tarihi dönemi (VI-XI. yüzyıllar arasındaki dönem ile XI-XIII. yüzyıllar arasındaki dönem olarak iki alt başlıkta inceler.), Oğuzcanın geçirdiği ikinci tarihî gelişme süreci (XII-XII. yüzyıllar arasını kapsayan dönem) ve üçüncü dönem (Oğuzların Orta Asya'dan uzak bir coğrafi bölgede, yani Anadolu'da bağımsız bir devlet kurduktan sonra (MS. 1071), XII. yüzyıl sonlarından başlayarak oluşturdukları Eski Anadolu Türkçesi Dönemi'dir) olarak üçe ayırmıştır (2005: 471-473).

ERCilasun, Eski Anadolu Türkçesinin; Anadolu Selçukluları Dönemi'ni, Beylikler Dönemi'ni, Karakoyunlu ve Akkoyunlu Dönemleriyle Osmanlı İmparatorluğunun ilk dönemini kapsadığını söyler (2014: 438). ŞAHiN, Eski Anadolu Türkçesini; Selçuklu Türkçesi, Beylikler Dönemi Türkçesi ve Osmanlı Türkçesine Geçiş Dönemi Türkçesi olarak üç devreye ayırdıktan sonra bu devirleri şöyle açıklar: Selçuklu Dönemi Türkçesine baktığımızda savaşlar ve karışıklık nedeniyle günümüze ulaşabilen eserlerin XIII. yüzyıl sonrasına ait olduğu görülmektedir. Selçuklu devletinin yıkılmasından Osmanlı devletinin bir imparatorluk haline gelmesine kadar geçen döneme Beylikler Dönemi denilmektedir. Bu dönemde Selçuklu devrinin aksine çok sayıda tercüme ve telif eser verilmiştir. Ayrıca Türkçeye dayalı yerli ve millî bir yazı diline geçiş bu dönemde gerçekleşmiştir. Osmanlı Türkçesine geçiş döneminde Arapça ve Farsçaya gösterilen ilginin artmasıyla beraber sade Türkçe ile yazma eğilimi yavaş yavaş terk edilmiştir. Edebî 


\section{$J(\Theta)$}

yönden oldukça yüksek bir seviyede bulunan Türk edebiyatı dil açısından bakıldığı zaman büyük bir düşüş yaşamıştır (2003: 14-29).

Eski Anadolu Türkçesi Dönemi'nde de ilk örneklerine IX-XII. yüzyıllar arasında rastladığımız dinî, tasavvufî ve ahlakî eserler verilmiştir. Selçuklular Dönemi'nde düşünce özgürlügünün bulunması Anadolu'da mezhep ve meşrep çeşitliliğinin artmasına sebep olmuş ve bu alanda verilen telif ve tercüme eser sayısını arttırmıştır. Özellikle, Mevlânâ’nın Mesnevî si, İran ve Türk edebiyatına büyük bir etki yapmıştır. İlahî aşk, insan-ı kâmil, ahlâkî eğitim, sohbet, tecellî, adab ve erkân, nefsin fenalıkları gibi konuların işlendiği bu eserlerin telif ve tercüme edilmesi halkın ruhî yükselişinde önemli yer tutmuştur (Bilgin 2007: 334-335). Dinî, tasavvufî ve ahlakî eserlerin telif ve tercümesine ilerleyen yüzyıllarda da devam edilmiştir. Eski Anadolu Türkçesi döneminde yazılan dinî, tasavvufî ve ahlakî eserlerin başlıcaları şunlardır: Ahmed Fakih'in Çarh-nâme'si, Mevlânâ'nın Mesnevîsi, Hacı Bektaş Velî̀nin Makalât'ı, Sultan Veled'in Maarifi, Yûnus Emre'nin Risâletü'n-Nushiyye'si, Gülşehrî̀nin Mantıku't-Tayr' ', Âşık Paşa'nın Garibnâme'si vb.

Eski Anadolu Türkçesi sahasında hem metin neşriyatı hem de müstakil dil bilgisi mevzuları hakkındaki çalışmalar, sayıca hayli artarak memnuniyet verici seviyeye ulaşmış bulunmasına rağmen, bu çalışmaların ihtiyaca cevap verici bir mükemmelliğe ve tamamiyete eriştiğini söyleyemiyoruz. Eski Anadolu Türkçesi metinlerinden günümüze ulaşmış olanlara ilave olunabilecek başka eserlerin de eksikleri giderici payının bulunduğunu kabullenmekle beraber, bizce asıl problem eldeki eserlerin kifayetsizliğinden ve Eski Anadolu Türkçesi üzerinde yapılan çalışmaların azlığından kaynaklanmaktadır (Turan 1999: 265). Bu nedenle tamamlama fikrinin de etkisiyle, eldeki tabakaları da dikkate alarak Firdevsînnin Hayât u Memât adlı eserini incelemeye karar verdik.

Çalışmamızın konusu olan Hayât u Memât isimli eser, Eski Anadolu Türkçesi dil ve imlâ özelliklerini yansıtması, bu dönemde tercüme edilen eserlerin özellikleri hakkında bilgi vermesi, dinî, tasavvufî ve ahlâkî konuları içermesi bak1mından önemli bir yere sahiptir. Bu özelliklerin ortaya konulmasının saha araştırmalarına katkı sağlayacağı ümit edilmektedir. 


\section{$J(\Theta)$}

\section{Firdevsînnin Hayatı, Edebî Kişiliği ve Eserleri}

Asıl adı Şerafeddîn Mûsâ olan Firdevsî, 857 (1453) yılında Edincik'te dünyaya gelmiştir. Firdevsî-i Rumî, Firdevsî̀-i Tavîl, Uzun Firdevsî ve Türk Firdevsî gibi isimlerle anılmıştır. Köklü bir aileye mensup olan Firdevsînnin soyu Alâaddîn Keykûbât dönemine kadar uzanmaktadır. Bazı kaynaklarda Bursalı olduğu bilgisi kayıtlıdır. Bunun sebebi öğrenimini Bursa'da görmesidir. Hayatı Edincik, Bursa, Manisa ve Balıkesir'de geçen Firdevsî bir müddet İstanbul'da da bulunmuştur. Nerede ve ne zaman öldüğü konusunda çeşitli rivayetler bulunmaktadır. II. Bayezid (saltanatı 1481-1512)'e sunduğu Süleymân-nâme isimli eserinin padişah tarafından uzun bulunması ve beğenilmemesi sebebiyle padişahı hicvedip İran'a kaçtığı söylenir. Ancak eserlerinden hareketle 1517 yılında İstanbul'da olduğu anlaşılmaktadır. Bu sebeple ölüm tarihinin 1517 sonrası olduğu düşünülmektedir (Köprülü 1996: 127-128).

Firdevsî, küçük yaşlardan itibaren tıp, tarih, felsefe, hendese, ilm-i nücûm, tasavvuf, doğu mitolojisi, şiir, satranç ve binicilik gibi pek çok alanla ilgilenmiştir. Bursalı Melîhî'den aruz bilgisini öğrenen Firdevsî’nin şiirde kabiliyetinin az olduğu söylenir. Ancak nesirde üretken bir yazar olarak anılmıştır. O, eserlerini farklı konularda sahip olduğu bilgileri göstermek için bir araç olarak kullanmıştır (Yılmaz 2013). Devrine göre sade bir dil kullanan yazarın eserleri öğretici niteliktedir. Muhtelif konularda kırktan fazla eseri olduğu söylense de bunlardan yalnızca on altı tanesinin ismi bilinmektedir (Köprülü 1996: 128).

Yazara şöhretini kazandıran Süleymân-nâme-i Kebîr, Hz. Süleymân'ın hikâyelerinin anlatıldığı manzum ve mensur karışık olarak yazılmış bir eserdir. Firdevsî̀ye "Uzun" lakabını kazandıran eserin 330, 360 veya 380 cilt olduğunu rivayet eden kaynaklar bulunmaktadır. Eserde tıp, tarih, felsefe, hendese ve ilmi nücûma ait çeşitli bilgiler yer almaktadır. Firdevsî, bu eserden önce Kıssa-nâmei Süleymân Aleyhisselâm isminde mensur bir kıssa-nâme telif etmiştir. Kutb-nâme: Kıssa-i Cezîre-i Midilli isimli manzum eserinde ise Midilli deniz harekâtını anlatır. Da'vet-nâme, astronomi konusunda yazdığı, içinde yüz kırk bir resim de bulunan mensur eseridir. Manzum ve mensur karışık olarak kaleme aldığı Münâzara-i Seyf ü Kalem, kalem ve kılıcın birbirlerine üstünlük sağlamaya çalışırken yaptıkları sembolik münazarayı anlattığı eseridir. Silahşör-nâme veya Müsellah-nâme adıyla 


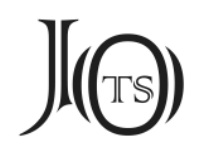

bilinen eserinde çeşitli silahları anlatır. Satranç-nâme-i Kebî' de ise satrancın tarihçesi ve teknikleri hakkında bilgi verir. NasîreddînTûsînnin Câmeşûy-nâme adlı eserini bir bölüm ekleyerek Farsçadan Türkçeye Tercüme-i Câmeşûy-nâme ismiyle tercüme etmiştir. Tuhfetü'l-Hâdî ve Hâcî Bektâş Velî Vilâyet-nâmesi isimli eserleri menkıbevi bilgiler içermektedir. Farsçadan tercüme ettiği Teşhîsü'l-İnsân ve sağlık konusunu ele aldığı Pend-nâme-i Eflâtûn dışında Firâset-nâme, Süleymân-nâme vü Belkıs-nâme, Hadîs-i Ahsen ve çalışmamızın konusu olan Hayât u Memât isimli eserleri bulunmaktadır (Yılmaz 2013).

\section{Hayât u Memât'ın Tanıtımı}

\section{II.1. Eserin Diş Özellikleri}

Eserin tek nüshası bulunmaktadır. Bu nüsha Süleymaniye Kütüphanesi, Hacı Mahmud Efendi numara 2333'te Hayât-nâme adıyla kayıtlıdır. Kaynaklarda eserin Hicrî 914, Milâdî 1508 tarihinde Farsçadan Türkçeye tercüme edildiği bilgisi yer almaktadır (Köprülü 1996: 129).

Eser XVI. yüzyılda kaleme alındığı için Eski Anadolu Türkçesinin dil özelliklerini taşımaktadır. Nesih yazı türünün kullanıldığı eserin satır sayısı 15'tir. Bununla beraber satır sayısının 16'yı bulduğu sayfalar $(6 a, 26 b)$ da mevcuttur. Eser 99 varaktan oluşmaktadır. Eserin ölçüleri ise 248x147-163x99'dur. Satır ve kapaklarının kenarları kahverengi meşindir.

Eserin zahriye kısmının arka yüzünde 291 tarihi kayıtlıdır. Aynı sayfada Mustafâ efendinügdür bu kitâb ibaresi de bulunmaktadır. Bu bölümün devamındaki sayfanın arka yüzünde ise eserin adı olan "kitâb-1 hayât u memât" yazısıyla beraber "te'lîf-i firdevsî” ifadesi de yer almaktadır. Bu ifadelerin altında ve sol tarafında bulunan yazılar karalandığı ve yıpranmaya uğradığı için okunamamıştır. Ayrıca bu sayfanın solunda eserin tercüme edildiği döneme ait olduğu düşünülen bir mühür ile birlikte Beşiktaş Vakıf Kütüphanesi, Süleymaniye kütüphanesi ve Hacı Mahmud Efendi bölümüne ait mühürler de bulunmaktadır.

Eserin 1a yüzünde yer alan başlığı tezhiplidir. Burada bulunan besmele-işerîf mavi mürekkeple yazılmıştır. Eserdeki başlıklar, ayetler, hadisler, fasılların numaralarını bildiren başlıklar, nazm, nesr, dahı, nite gibi ifadeler kırmızı mürekkeple kaydedilmiştir. 2a'dan itibaren ön yüzünün sağ üst kısımlarında Arapça 


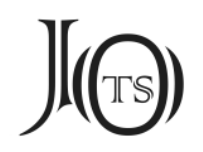

ibareler yer almaktadır. Ayrıca 35b numaralı sayfanın sol üst kısmında metinde yer alan şiirin vezni olan "fấcilâtün fấcilâtün fấcilün" ile ki düriş kim içesün âb-ı hayât mısrası der-kenar olarak kayıtlıdır.

Eser üzerinde Fatih Sultan Mehmet Vakıf Üniversitesi Tarih programında Fatma Atasoy ÇALIŞKAN tarafından Firdevsî-i Tavîl' in Kitâb-ı Hayât ü Memât Adlı Eseri: Tahlil ve Metin adıyla yüksek lisans tezi yapılmıştır. Çalışma, üç bölümden oluşmaktadır: Birinci bölümde Firdevsî-i Tavîl'in hayatı ve eserlerini konu alınmış, ikinci bölümde eser hakkında detaylı bilgi verilip, eserin tercüme olup olmadığı çözümlenmeye çalışılmış, son bölümde ise eserin kaynak değeri ele alınıp, dibace ve otuz bâbdan oluşan eserin özeti yapılmıştır. Sonuç ve bibliyografyadan sonra metnin transkripsiyonu da verilmiştir. Tarafımızca eser, transkripsiyonu yanı sıra dil incelemesi, dizin ve sözlük çalışmalarıyla ilmî olarak yayınlanma ve Firdevsînin söz varlığını bu eser tanıklığında ortaya koyma arzusuyla da ele alınacaktır.

\section{II.2. Eserin Muhtevas1}

Eser, besmele-i şerîfin ardından Allah'a hamd edilen bir giriş bölümüyle başlar. Sonra $1 \mathrm{~b}$ numaralı sayfada yer alan tevhîd bârî té âlâ 'azze şânühü başlığıyla tevhid bölümüne geçilir. Bu bölümde Allah'ın isimlerinin ve sifatlarının yer al-

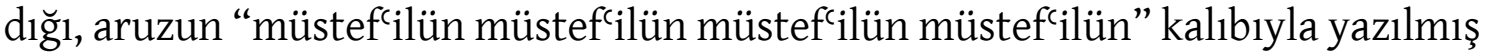
bir şiire yer verilmiştir. Bu şiir 2a'nın 7. satırına kadar devam eder.

2a numaralı sayfada münacat bölümü başlar. Bu bölüme ender-münâcât musannif-i kitâb-ı firdevsî zấefallâhü kadrehü başlı̆̆ı verilmiştir. Burada Allah'a sultân, pâdişâh, ilâhî gibi ifadelerle seslenilerek kaza ve kadere duyulan iman dile getirilir. Bu bölümün sonunda aruzun "mefâ̂̂̂lün mefâ̂̂̂lün fecûlün" kalıbıyla yazılmış bir şiir bulunmaktadır. Bu şiir, 2b'nin sonuna kadar devam eder.

3a numaralı sayfada Hz. Muhammed'i öven bir naat bulunmaktadır. Derna't-ı resûl-i kevneyn seyyidü's-sakaleyn ve imâmü'l-kıbleteyn hâtemü'n-nebiyyin şefi'ü'l-müznibîn Muhammed Mustafa sallallâhü'aleyhi ve sellem ifadesi başlık olarak verilmiştir. Hz. Muhammed için bu bölümde 'andelîb-i çemen-ârâ, mâh-ı âsumân-ı sıdk, münşîli dîvân, sitâre-i âsumân gibi benzetmeler yapılmıştır. Naat bölümünde 


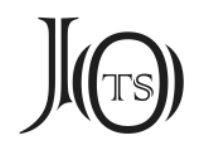

4a numaralı sayfanın 8. satırına kadar süren, aruzun "mefâcîlün mefấîlün fecûlün" kalıbıyla yazılmış bir şiire yer verilmiştir.

4a numaralı sayfanın 9, 10, 11 ve 12 . satırlarında dönemin sadrazamı olan Mustafa Paşa'ya yazılııs bir övgü bulunmaktadır. Onun cömertlik kaynağı, vefa ve huzur madeni olduğunu dile getiren ifadeler kullanılmıştır.

Eserin 4a numaralı sayfasının 13. satırında Farsçadan Türkçeye tercüme

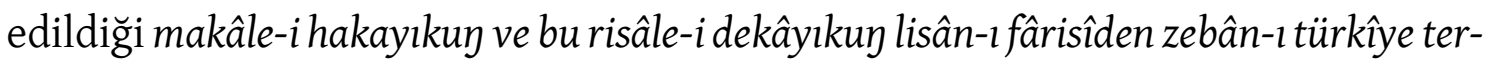
cüme olduğına cihet ifadesiyle belirtilmiştir. Aynı sayfanın 15. satırında ise eserin rebiü'l-evvel ayında Konstantiniyye'de yazıldığını belirten cümleler yer almaktadır. 5a numaralı sayfanın 15. satırında ise meşâyih-i kibâr risâlelerinden imâm-ı gazâlî ve şeyh muhyiddîn 'arabî ve șeyh 'attâr makâlelerinden intihâb kılup türkîye tercüme olındı denilerek eserin kaynakları hakkında bilgi verilmiştir.

5 b numaralı sayfanın 3. satırında eserin 30 bâbdan oluştuğu belirtilir. Aynı sayfanın 7. satırından başlayarak 6b numaralı sayfanın 9. satırına kadar bâbların içeriği hakkında birer cümlelik özetlere yer verir. Bu özetler şu şekildedir:

bâb: Mevlânâ'nın Şems-i Tebrîzîye nefs hakkında soru sorması ve onun da cevap vermesini içerir.

bâb: Mevlânâ'nın Şems-i Tebrîzîyi eşyâ-i küllî hakkında sorular sorarak imtihân edip onun da cevap vermesini içerir.

bâb: Nefs-i küllînin cism-i küllîye bağlı olmasının asıl sebebinin ne olduğunu içerir.

bâb: Mevlânâ'nın Şems-i Tebrîzîye nefs-i küllînin sirâyetini sorması ve onun da cevap vermesini içerir.

bâb: Ölüme ve hayata itibâr etmenin ne olduğunu içerir.

bâb: Ölümün, hayâtın ve cismin niteliklerinin ne olduğunu içerir.

bâb: Umûr-1 cüziyye ile nefs-i emmâre hakkında soru ve cevapları içerir.

bâb: Ölümün hikmet olduğunun ne anlama geldiğini içerir.

bâb: Ölümü araştırma ve teşhis etmenin yollarını içerir.

bâb: Öldükten sonra hangi mertebeli kişilere rahmet edileceği, hangi dereceli kişilere azap edileceğini içerir. 


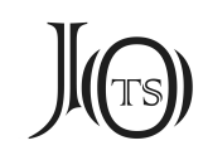

bâb: Nefsin kuvvetinden fiile çıkmanın nasıl olduğunu içerir.

bâb: Siyâsetten kastın ne olduğunu içerir.

bâb: Nefsin ayıplarını ve bunların örneklerini içerir.

bâb: Nefsin hallerini içerir.

bâb: Hayvanların ölümü kerih görmelerinin sebeplerini içerir.

bâb: Lezzet, elem, rahat ve sıkıntı görmenin sebeplerini içerir.

bâb: Nefs-i emmâre ile umûr-1 cüziyye hakkında bilgileri içerir.

bâb: Hâl ehli ile nâr ehli arasındaki farkları içerir.

bâb: Küfür ve kâfir hakkında bilgileri içerir.

bâb: Cehennem ehli hakkında bilgileri içerir.

bâb: Evliyâların ebediliğe, cahillerin faniliğe rağbet etmesinin sebeplerini içerir.

bâb: Yaratılmışların ahlâkı ve amellerinin birbirine benzememesinin sebeplerini içerir.

bâb: Özet kısmında bu bâbla ilgili bilgi verilmemiştir. Bu bâb ruhânî lezzetler ve nefsânî acıları içerir.

bâb: İnsanla melekler arasında ortak olan yönleri içerir.

bâb: Kötü amellerin ve kabahatli işlerin ne olduğunu içerir.

bâb: Allah'ın birliğine inananların itimâdını ve taklitçilerin itimâdını içerir.

bâb: Âlemin kanunları hakkında bilgileri içerir.

bâb: Nefsin, lezzetten ve elemden ferâgât etmesini içerir.

bâb: Vezirlerin, kalem erbâbının, dergâh bekçilerinin sülükü hakkındaki bilgileri içerir.

bâb: Mustafa Paşa hakkında bilgileri içerir.

Eserde tasavvuf, ahlak, nefs, hayat, ölüm, cennet, cehennem, küfr, rahat, elem, iyi ve kötü ameller gibi konularda bilgiler verilmektedir. Bu bilgiler; kimi zaman ayetlerle, kimi zaman hadislerle kimi zaman da şiirlerle süslenerek açıklanmıştır. 


\section{J(৫)}

\section{Eserin İmlâ Özellikleri}

\section{III.1. Ünlülerin Yazılışları}

\section{/a/ Ünlüsünün Yazılışı}

Eserde kelime başlarında bulunan /a/ünlüsü elif (I), üstünlü elif (I) ve bazen de medli elif (I) ile yazılmıştır. Kelime içinde elif (I), üstünlü elif (i) ve sadece üstün ile verilmiştir. Kelime sonunda ise güzel he (॰), kısmen de elif (I) ile gösterilmiştir:

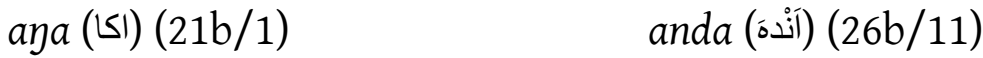

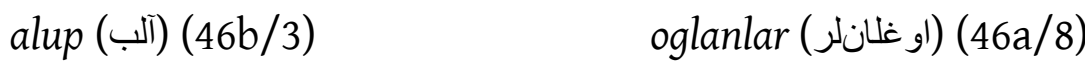

$$
\begin{aligned}
& \text { salar (صنالر) (26b/12) ola (5b/6) }
\end{aligned}
$$

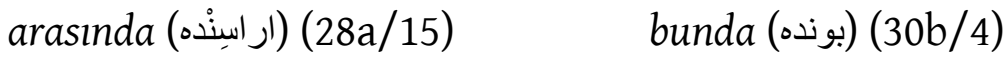

\section{/e/ Ünlüsünün Yazılışı}

Kelime başında yer alan /e/ ünlüsü elif (I) ve üstünlü elif (I) ile yazılmıştır. Kelime ortasında harekeli veya işaretsiz olarak ya da güzel he (॰) ve elif( (I) ile gösterilmiştir. Kelime sonunda ise güzel he (o) ve üstünlü güzel he (o) ile kullanılmıştır:

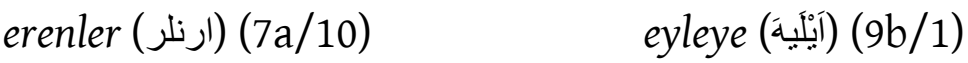

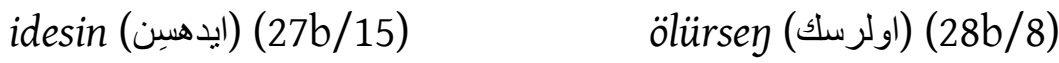

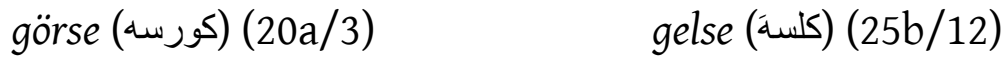

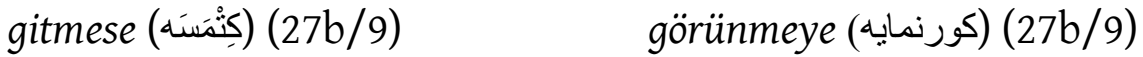

Bilindiği üzere Eski Türkçeden beri kök hecede /e/ veya /i/ sesini barınd1ran kelimelerle ilgili bir e-i meselesi varlığı aşikârdır ve /e/ mi /i/'den, /i/ mi /e/'den gelmektedir konusu tartışılagelir: e/i meselesi süreçlere bağlıdır ve süreçler halinde vardır. Yani nereden nereye gittiği süreçler ile alâkalıdır. Bir süre Arap alfabesi ile Uygur alfabesinin yan yana kullanılmış olmasından dolayı, Orta Asya'da kullanılan imlâ ile bu durumdan daha az etkilenen Anadolu coğrafya- 


\section{$J(\Theta)$}

sında kullanılan imlâ arasındaki fark açıktır. Hatta bazen tamamen Arapçada olduğu gibi imlâda ünlülerin hiç kullanılmadığı da olmuştur. İlk bakışta çok karışık gibi görülen bu imlâ ve dolayısıyla /e/ve/i/meselesi, halli hususunda, bir tarafta /e/ bir tarafta /i/ bulunmasına bakarak, bu iki sesi kendinde toplayan bir kapalı /é/ kabul ve bunun sonradan /e/ ve /i/ şeklinde gelişimi tasavvur edilir (Arat 1953: 306-313)

EMRE'nin “Türkçede Bulanık e (é) Fonemi” (1946: 487-497) adlı makalesine göre Yakutça /ie/ diftongu yarı dar e ünlüsünün en eski biçimidir ve bu diftongun büzülmesi sonucu /e/, /é/, /i/, /î/ sesleri ortaya çıkmıştır. Sonuç olarak /é/ sesi eski bir diftongun bıraktığı izden başka bir şey değildir.

CEYLAN'a göre ise (1991: 160), Eski Anadolu Türkçesi ve Osmanlıcada kök hecede /e/ sesi için $\checkmark$ ye yazılışı yaygındır. Türkologlar çoğunlukla, bugün Türkiye Türkçesinde e ile söylenip de Eski Anadolu Türkçesi ve Eski Osmanlıcada ⿶ ye ile işaretlenmiş köklerde bir /é/ görme eğilimindedirler. Fakat FoY XIII. yüzyıl Osmanlıcasında bu sesin /i/ olduğu inancındadır (1900:3). FoY’a göre Köktürkçe gibi Osmanlıcada da aynı diyalekt içinde /e/ ve /i/'li çift biçimler vardır (1900: 215). Foy'un /i/'li okuyuşunu yerinde bulmayan NEMETH, çift yazıllışları /é/'nin kanıtı sayar (1939: 518).

Timurtaş'a göre, eski imlâmızda kapalı /é/'nin varlığını belirtecek bir işaret ve harfin olmayışı bu husustaki tespiti ve kararı zorlaştırmaktadır. Eski Türkiye Türkçesi metinleri üzerinde araştırma yapanların bazıları /i/'yi /é/ kabul etmelerine karşılık bazıları aslî yazılışa sadık kalmaktadır (Timurtaş 1994: 21). Biz, metnimizde ikinci tercihi takip ettik ve bunu bir mesele olarak değil denklik olarak değerlendirdik: /e/:/i/.

\section{/1/ ve /i/ Ünlülerinin Yazışı}

Metnimizde kelime başında bulunan /1/ ve /i/ ünlüsü elif (I), esreli elif (I) ve elif-ye (إ) ile yazılmıştır. Kelime ortasında harekesiz veya esre (০), ye (ي) ve esreli ye (ي) ile gösterilmiştir. Kelime sonunda ise ye (ي) ve esreli ye (ي) ile:

$$
\begin{aligned}
& \text { iste (إسته) (24b/12) } \\
& \operatorname{lra\dot {g}} \text { (ايرغ (33b/5) } \\
& \text { indi (اندي) (45b/4) } \\
& \text { didügi (دِدُوكي) (27a/14) }
\end{aligned}
$$




\section{J(৫)}

nitekim (نتهكم) (28b/3)

yir $($ iير) (38a/1)

idi (ايدي) (26b/15)

$i k i($ اكي $)(30 b / 5)$

\section{/o/ ve /ö/ Ünlülerinin Yazışı}

“o-ö” ünlüleri kelime başında elif-vav (او), ötreli elif (l) ve ötreli elif-vav (و) ile gösterilmiştir. Kelime ortasında ise vav (و) veya ötrelivav (و) ile yazılmıştır. Türkçe kelimelerin sonunda "o-ö" harfleri bulunmaz. Metnimizde de bu örneklere rastlanmamıştır:

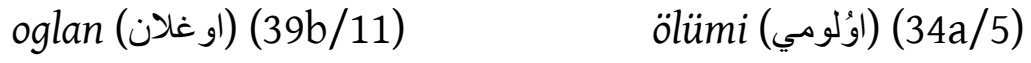

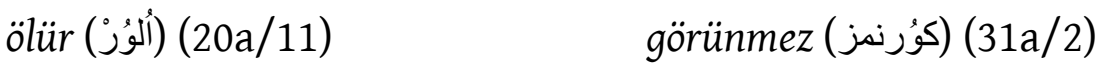

$$
\begin{aligned}
& \text { söylenüp (اولاولاوبلنوب) (29a/10) }
\end{aligned}
$$

\section{/u/ ve /ü/ Ünlülerinin Yazışı}

Kelime başında bulunan /u/ ve /ü/ sesleri elif-vav (و (و) ve ötreli elif-vav (وا) ile yazılmıştır. Kelime ortasında ötre, vav (و) ve ötreli vav (و) ile kullanılmıştır. Kelime sonunda vav (و) ve ötreli vav (و) ile işaretlenmiştir:

$$
\begin{aligned}
& \text { unutdurur (اوُنتنورر) (31a/9) (49b/8) }
\end{aligned}
$$

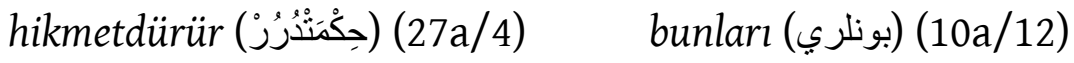

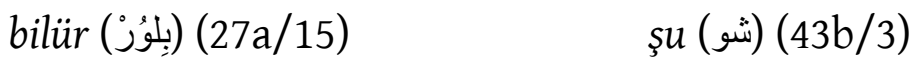

$$
\begin{aligned}
& \text { su (صو (27b/7) (4ؤ) (27b/9) b }
\end{aligned}
$$

\section{III.2. Ünsüzlerin Yazılışları}

\section{/ç/ Ünsüzünün Yazilışı}

Metinde /ç/ ünsüzü kelime başı, ortası ve sonunda bazen cim (ج) bazen de çim (๕) ile gösterilmiştir. Ancak tarafımızca bir imlâ meselesi olarak görülen morfo-fonetik olarak bu tabakalı kullanımdaki kelimeler /ç/ olarak okunmuştur:

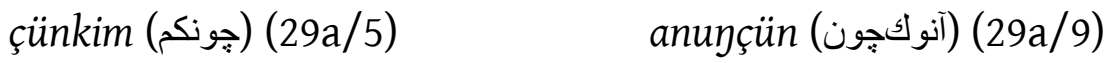

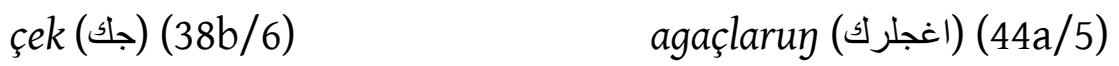

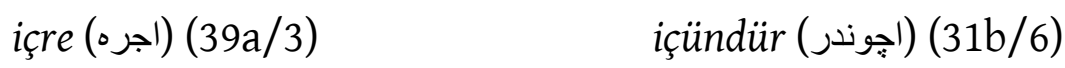




\section{$J(\Theta)$}

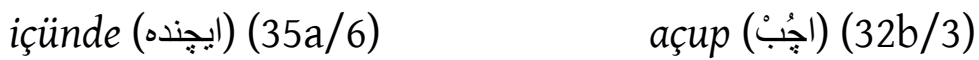

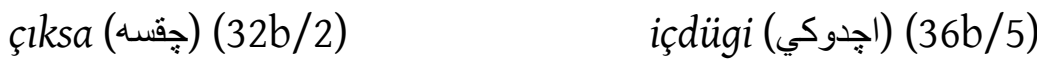

\section{/y/ Ünsüzünün Yazilışı}

/y/ ünsüzü metinde kef(S) ile yazılmıştır. /g/ ve /k/ sesini de karşılayan kef (ك) harfiyle /y/ ünsüzünü ayıran bir işaret kullanılmamıştır:

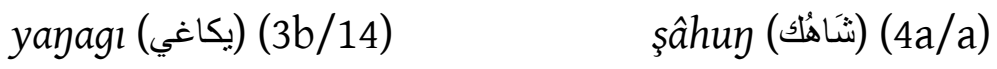

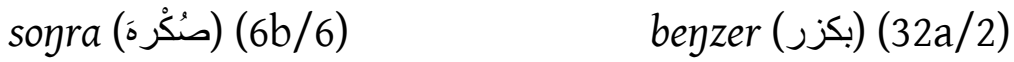

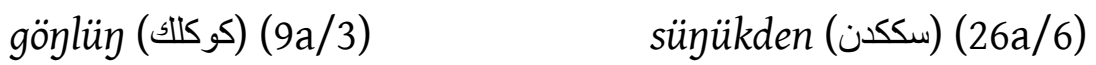

$$
\begin{aligned}
& \text { big (بيك) (14b/15) (35ز) (38b/11) degiz }
\end{aligned}
$$

\section{/p/ Ünsüzünün Yazilı̧̧ı}

Kelime başı, ortası ve sonunda yer alan /p/ ünsüzü ve zarf-fiil eki \{-(y)Up\}, be (ب) ile verilmiştir. Yine bir imlâ meselesi olması hasebiyle zarf fiil eklerinde /p/ sesiyle okuma tasarrufunda bulunulmuştur:

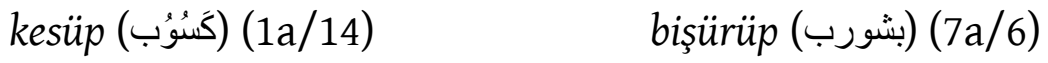

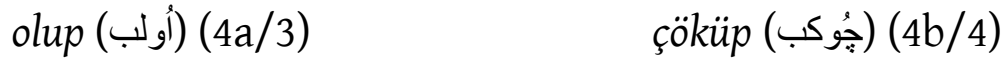

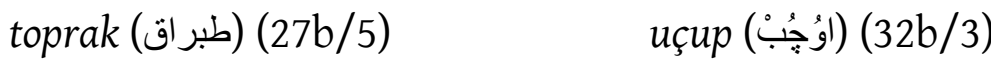

\section{/t/ Ünsüzünün Yazılışı}

Metinde art ünlülü kelimelerde yer alan / $t /$ sesi bazen $t \imath$ (b) bazen de dal (د) ile yazılmıştır. Eski Anadolu Türkçesinde kelime başı /t/ sesinin ötümlüleştiği bilinen bir durumdur. Ancak art ünlülü kelimelerde bu /t/ sesinin bazen ötümlüleşmeye direnerek aşırı patlayıcı bir sese dönüştüğünü metnimizde görüyoruz. Aşırı patlayıcı sesler, normal ötümsüzlere göre daha önde boğumlandığı halde ötümsüzlüğünü muhafaza eden, bir derece nefesli olmalarına rağmen hafif gırtlak darbeli ve gergin oldukları için diğer patlayıcılara göre daha ani patlamalı olmak gibi farklı özellikleri barındıran mürekkep bir ara merhale sesi niteliklerine sahiptirler (Turan 1999: 554). Kıpçak Türkçesinin etkisiyle ve ötümsüzlüğü 


\section{J(G)}

muhafaza direnciyle ön seste aşırı patlayıcılaşma ses olayı metnimizde de örneklenmiştir:

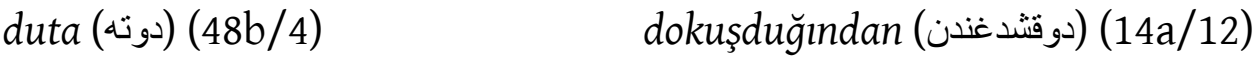

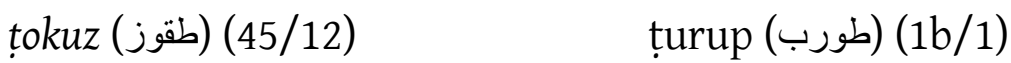

\section{/ḳ/ ve/g் Ünsüzlerinin Yazılışı}

/k/ ünsüzü kaf(ق) ile / $\dot{g} /$ ünsüzü gayın (غ) ile gösterilmiştir:

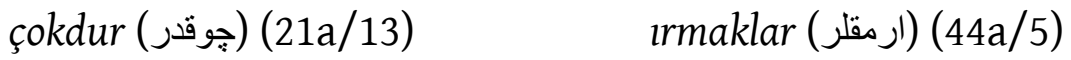

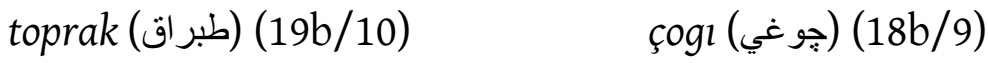

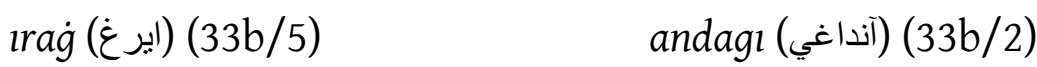

\section{/s/ Ünsüzünün Yazilışı}

/s/ ünsüzü art ünlülü kelimelerde sad (ص) ile ön ünlülü kelimelerde ise sin (س) ile yazılmıştır:

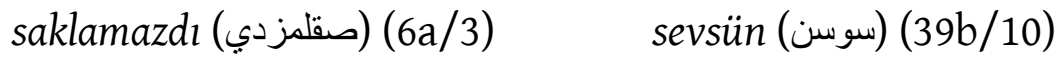

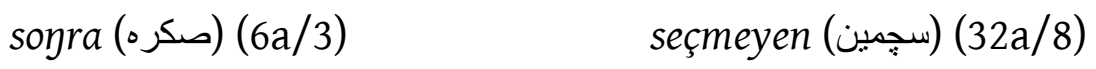

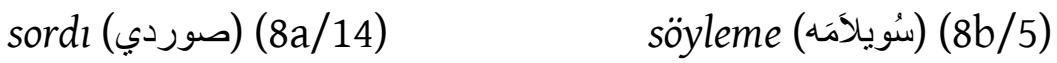

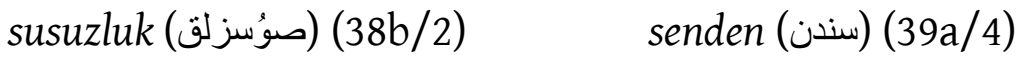

\section{III.3. Bazı Kelime ve Eklerin İmlâları}

\section{Kim ve Ki'nin Yazılışları}

kim ve ki kendinden önceki kelimeye bazen bitişik, bazen de ayrı yazılmıştır:

ne kim (نكم) (6b/13) ne kim (نَه كَمْ (18a/8)

kaçan ki (قنجنكة) (8b/8) kaçan ki (قجن كه) (26a/1)

\section{İle'nin Yazılışları}




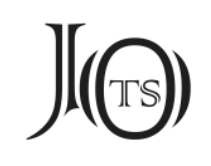

ile sözcüğü metinde bazen kendisinden önceki kelimeden ayrı bazen bitişik olarak gösterilmiştir. Bitişik yazılan örnekler okunurken Türkçenin temel kurallarından olan ses uyumuna dikkat edilmiştir. Kural gereği kelimeye getirilen eklerin hem ünlüleri hem de ünsüzleri uyuma girer. Yani yayınma hadisesiyle birlikte kök kelimede bulunan seslerin nitelik ve nicelikleri, üzerine getirilen yapım ve çekim eklerine yayınır (Ergüzel-Aydın 2010: 157):

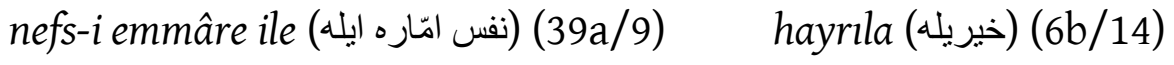

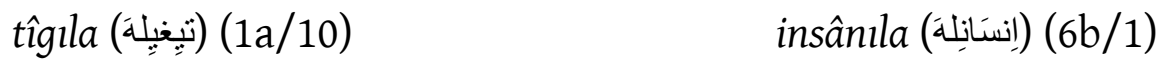

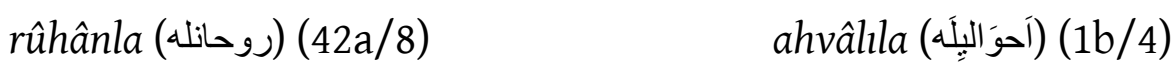

$$
\begin{aligned}
& \text { mevlânâ ile (مو لانائلة) (8a/2) (39a/11) }
\end{aligned}
$$

\section{i- Cevherî Ek Fiilinin Yazılışları}

\begin{tabular}{|c|c|}
\hline varıdı (وَارِدِي) (7a/9) & gülzârıdı (كلز اريدي) (41a/2) \\
\hline insânıken (انسانيكن) (38b/9) & nebâtiken (نباتيكن) (41a/8) \\
\hline ekmâli idi (اكمالي ادي) (7a/15) & iderken (ادركن) (7a/11) \\
\hline
\end{tabular}

\section{İçün Sözcüğünün Yazılışları}

içün sözcüğü bazen kendinden önceki kelimeye bitişik bazen de ayrı olarak yazılmıştır:

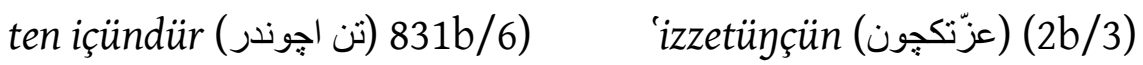

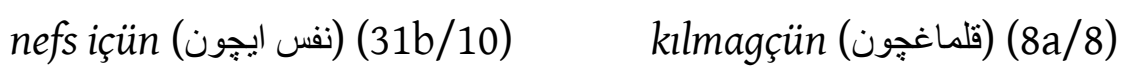

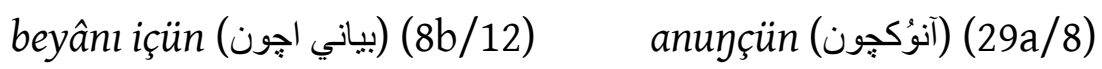

\section{De'nin Yazılışı}

'Dahi' anlamına gelen de kendinden önceki kelimeye her zaman bitişik yazılmıştır:

sen de (سندم) (19a/8) (21b/13) (22b/4) (48b/12)

\section{Kadar Sözcüğünün Yazılışı}




\title{
J(৫)
}

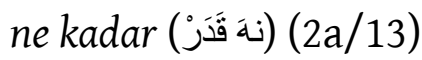

ol kadar (اؤل قدر) (2a/14)

bu kadar (بو (7b/15)

\section{Soru Ekinin Yazılışları}

Metinde soru eki kelimeye bitişik yazılır:

\author{
varml (وارمي) (7b/5) yokml (يوقيم) (7b/5)

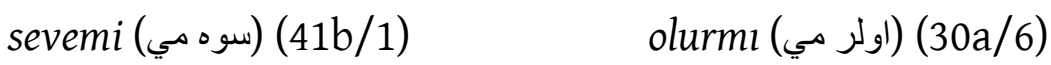

\section{Tenvin İşaretinin Kullanılışı}

Metinde yer alan Türkçe kelimelerde tenvin kullanılmamıştır. Ayetlerde bulunan bazı Arapça kelimelerde bu hareke işaretlenmiştir:

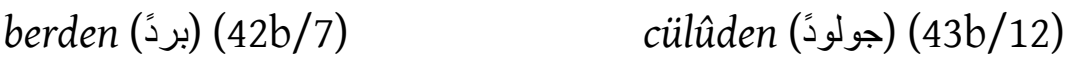

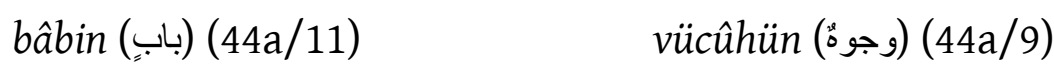

\section{Şedde İşaretinin Kullanılışı}

Metinde Arapça kelimelerin yanında bazı Türkçe kelimelerde de şedde kullanılmıştır:

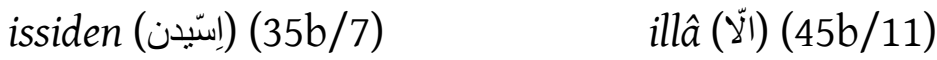

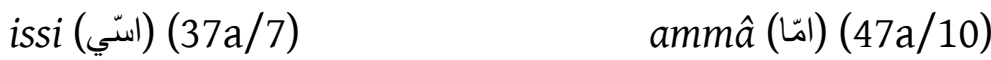

\section{Sonuç}

Eseri incelediğimizde Eski Anadolu Türkçesinin karakteristik özelliklerini yansıttığını görürüz. Bunlar gelüp (< kel-), düzetdi (< tüzet-), pîrliğe < pîrlik+e örneklerinde görüldüğ̈̈ üzere ötümlüleşme, atlu (< atlıg), ayru (< ayrı < adrıg), kapusına (< kapıg) örneklerinde görüldüğü üzere yuvarlaklaşma, dürlü (< türlüg), atlu (< atlıg) örneklerinde görüldüğg̈ üzere erime, olan (< bolgan), gerek (< kergek) örneklerinde görüldüğ̈̈ üzere yutulma vb. şeklinde sıralanabilir. Bunların dışında țokuz (طقوز) (45/12), țurup (1b/1) gibi aşırı patlayıcılaşma örneklerine de rastlanılmıştır. 


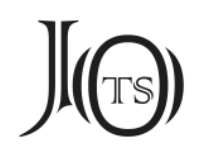

Mevlana ile Şems arasında geçen diyaloglardan oluşan eser; tasavvuf, nefs, hayat, ölüm, cennet, cehennem, iyi ve kötü ameller gibi konuları işlemesi bak1mından önemli bir yere sahiptir. Eser, ayrıca Firdevsî’nin edebî kişiliğini yansıtmaktadır. Kaynaklarda yer alan bilgilere göre nesirde üretken olan Firdevsî’nin nazımda ise yetersiz olduğu söylenmektedir. Çalışmamızın konusu olan metinde yer alan şiirlere baktığımızda vezin hususunda çok sayıda hata yapıldı̆̆g görülmektedir. Bu durum, kaynaklarda yer alan bilgileri doğrular niteliktedir.

Çalışmamızda eser; dış özellikleri, muhtevası, dil ve imlâ özellikleri bakımından tanıtılmıştır. İmladan kastımız; sadece bir harf ya da şekli değil, harflerin veya şekillerin birleşip birleşmeme ve hareke veya harflerin tercih sebeplerini de içine alan sesi yazıya geçirme disiplinidir.

Ayrıca eser üzerine yaptığımız yüksek lisans çalışmasında (Çetinkaya 2020) Hayât u Memât'ın dizini ve bağlama dayalı sözlüğü hazırlanarak söz varlığı ortaya koyulmaya çalışılmıştır.

Yukarıda saydığımız özellikler bakımından kıymetli olan eser üzerine yaptığımız çalışmanın saha araştırmacılarına faydalı olmasını ümit etmekteyiz.

\section{Kaynakça}

ARAT, R. R. (1953). "Türkçe Metinlere e/i Meselesine Dâir", Rocznik Orientalistyczny, 17: 306-313.

BilgiN, A. (2007). “Türk Tasavvuf Edebiyatı Literatürü”, Türkiye Araştırmaları Literatür Dergisi, 10/5: 334-335.

BüKE, H. (2015). “Firdevsî-İ Rumî, Hayatı ve Eserleri Hakkında Yeni Bilgiler”, Mehmet Akif Ersoy Üniversitesi Sosyal Bilimler Enstitüsü Dergisi, 13: 481-501.

BÜYÜKKARCi-YILMAZ, F. (2013). "Firdevsî, Şerefeddîn Mûsâ, Uzun Firdevsî, Firdevsîi Rûmî, Firdevsî-i Tavîl, Türk Firdevsî, (Türk Edebiyatı İsimler Sözlüğü, online)

Ceylan-Yilmaz, E. (1991). “Ana Türkçede Kapalı e Ünlüsü”, Türk Dilleri Araştırmaları, 1:151-165.

ÇAlişKan-ATasoy, F. (2019). Firdevsî-i Tavîl'in kitâb-1 Hayât ü Memât Adlı Eseri: Tahlil ve Metin, Fatih Sultan Mehmet Vakıf Üniversitesi, Lisansüstü Eğitim Enstitüsü, Tarih Anabilim Dalı, İstanbul. (Yayımlanmamış Yüksek Lisans Tezi) 


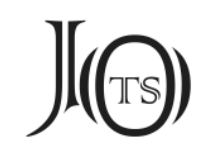

ÇETinKAYA, A. (2020). Kitâb-1 Hayât u Memât (Giriş-İnceleme-Metin-Dizinler), Sakarya Üniversitesi, Sosyal Bilimler Enstitüsü, Türk Dili ve Edebiyatı Anabilim Dalı, Sakarya. (Yayımlanmamış Yüksek Lisans Tezi)

DevelLioĞLu, F. (2007). Osmanlıca-Türkçe Ansiklopedik Lugat, Ankara: Aydın Kitabevi.

EmRE, A. C. (1946). “Türkçede Bulanık e (é) Fonemi”, Türk Dili-Belleten, III/6-7: 487-497.

ERCilasun, A. B. (2014). Başlangıçtan Yirminci Yüzyıla Türk Dili Tarihi, Ankara: Akçağ Yayınları.

ERGÜZEL, M. \& M. AYDiN (2010). “Eski Anadolu Türkçesinde Yapım Ekleriyle Türkçeleşen Arapça, Farsça Kelimelerin İmlâsı ve İbn-İ Âdil Melhamesi'nden Yansımalar”, Uluslararası Eski Anadolu Türkçesi Araştırmaları Çalıştayı Bildirileri, Eds. E. DoĞAN \& M. ÖZKAN, İstanbul Üniversitesi Yayınları, İstanbul: 157-169.

Foy, K. (1903). “Azerbajganische Studien mit einer Charakteristik des Südtürkischen I", Mitteilungen des Seminars für Orientalische Sprachen, 6: 126-193.

Foy, K. (1904). “Azerbajganische Studien mit einer Charakteristik des Südtürkischen II”, Mitteilungen des Seminars für Orientalische Sprachen, 7: 197-265.

KorkMAZ, Z. (2005). “Eski Anadolu Türkçesinin Türk Dilindeki Yeri”, Prof. Dr. Fikret Türkmen Armağanı, Kanyılmaz Matbaası, İzmir: 471-473.

KöPRÜLÜ, O. F. (1996). “Firdevsî, Uzun”, Türk Diyanet Vakfi İslâm Ansiklopedisi 13, Türk Diyanet Vakfı Yayınları, İstanbul: 127-129.

NÉMETH. (1939). “Zur Kenntnis des Geschlossenen e im Türkischen”, Körösi Csoma-Archivum, 1: 515-531.

Sami, Şemseddin. (2005). Kâmûs-1 Türkî, İstanbul: Çağrı Yayınları.

ŞAHIN, H. (2003). Eski Anadolu Türkçesi, Ankara: Akçă̆ Yayınları: 13-29.

TimuRTAş, F. K. (1994). Eski Türkiye Türkçesi, İstanbul: Enderun Yayınevi.

TimURTAŞ, F. K. (2011). Osmanlı Türkçesi Grameri (Eski Yazı ve İmlâ, Arapça, Farsça, Eski Anadolu Türkçesi), İstanbul: İstanbul Üniversitesi Edebiyat Fakültesi Yayınları.

TuRAN, Z. (1999). “Eski Anadolu Türkçesinde Ol- Cevheri Fiili”, Türk Dili Araştırmaları Yıllığı-Belleten, 44: 265-289. 


\section{J(G)}

TURAN, Z. (2012). "Orta Türkçe Metinlerinde Kelime Başı Ünsüzlerinde Aşırı Patlayıcılaşma Var Mıydı?”, İstanbul Üniversitesi Edebiyat Fakültesi Türk Dili ve Edebiyatı Dergisi, 30: 539-558. 